\title{
Assessment and improvement of the Moscow residential real estate market's environmental friendliness by sharing economy principles
}

\author{
Anna Schmeleva, \\ ${ }^{1}$ Plekhanov Russian University of Economics, 117997, Russian Federation, Moscow, Stremyanny \\ Lane, 36,
}

\begin{abstract}
Sharing economy platforms transform traditional production and consumption systems in cities around the world. While the sharing economy aims to increase the resilience of different economic systems, its actual economic, social, and environmental effects remain underresearched. During the pandemic of Covid-19, economic and environmental crises, and growing uncertainty, it becomes essential to promote sustainable and promising forms of shared (distributed) resources. Ways to benefit from the sharing economy's advantages, despite the significant number of Russian and foreign publications, are still poorly understood. At present, it is crucial to explore the roles, perspectives, and effects of both resource owners and users and Russian interaction platforms. Let us look at this sharing economy's development aspect on the example of the Moscow real estate market, taking into account the environmental impact of the large-scale housing renovation program. There have been identified some digital environmental IT platforms aimed at improving the efficiency of transfer and use of information resources (the main principle of sharing - to improve the efficiency of resources and information, in this case - environmental) on the environmental situation in Moscow and the region to inform the public about the opportunities and the primary environmental risks in housing purchase or construction.
\end{abstract}

\section{Introduction}

Moscow has always been and probably will continue to be the central Russian city. Since Soviet times, there has been an opinion that the products in Moscow are better, the city is cleaner, and the income is higher compared to other cities. Indeed, Moscow is still one of the leading Russian cities in terms of living standards [1]. However, other life quality criteria are worth consideration. Recently, Moscow has been breaking records not only in subway and road construction, real estate transactions, housing costs but also in atmospheric pressure, precipitation. All this has a direct impact on the residents increasingly concerned with stable quality of life in the capital. Moscow citizens, like most Russians, consider their and their family members' health as their principal value, and only

\footnotetext{
*Corresponding author: schmelevaanna@mail.ru
} 
then the notorious housing issue. A healthy person desires to work for material benefits; he has an opportunity to fully use social infrastructure and enjoy life and the world around him. The problem of preservation and maintenance of Moscow citizens' health becomes paramount in the conditions of continually breaking records of urban and ecological environment [2-4], taking into account the concepts of capital digitalization and sharing economy. Several publications in mass media and scientific literature have been devoted to assessing the digitalization's impact on various Russian activities [5-13]. In this research, the authors tried to address several questions related to introducing digital and sharing economy tools into Moscow's urban environment, including the housing renovation program that currently has no analogs in the country.

Sharing economy usually means "joint consumption economy" or "joint economy". This concept is widely used when discussing the digital economy's prospects, but its meaning is far from clear. Nowadays, one can only observe the "rudiments" of the Russian economy of distributed use. The concept of "sharing" (economy of shared use) has slowly but surely entered the Russians' everyday life. In European countries, sharing has developed to such a concept as commoning, which means a collective, participatory process of accessing, managing, and developing a resource [14]. The term "sharing economy" is mentioned for the first time in the paper by Botswana R. and Rogers R. [15] and is often considered as an object of economic science research [16-22] (Fig. 1). So far, there is no generally accepted definition of this concept.

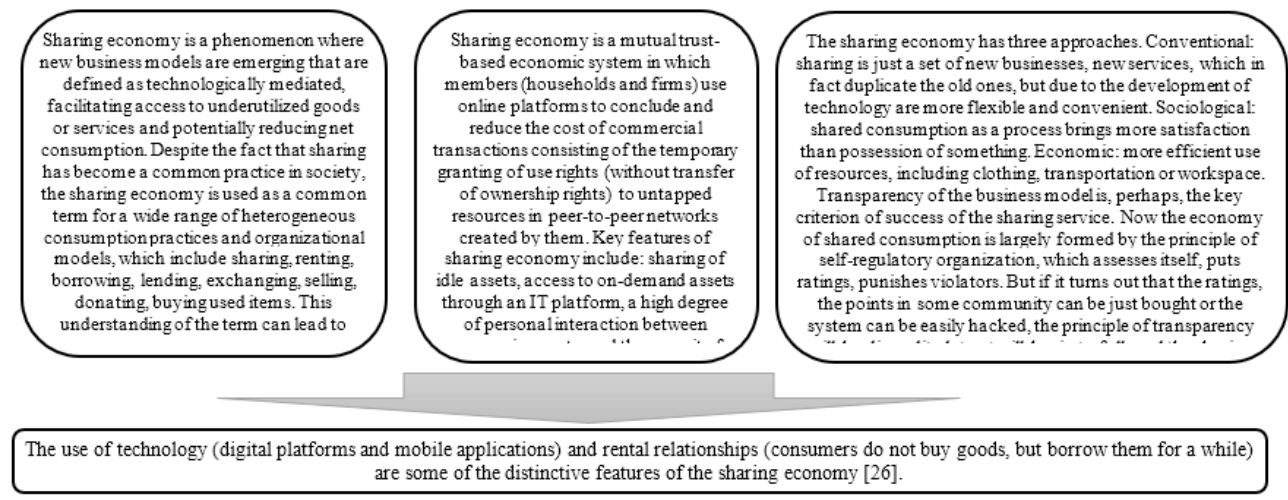

Fig. 1. Sharing economy - a study subject of economic science.

According to S. Izmalkov (a professor at the New Economic School, in 2002-2008, he was a professor at the Department of Economics at the Massachusetts Institute of Technology), sharing is an ephemeral concept not related to some fundamentally new form of ownership or use of goods or services. The whole concept implies a more intensive use of a resource or time with new digital technologies. Therefore, the concept is likely to disappear, and the prospects are much better for businesses based on a quick and effective search for deals with specific customers and allowing ordinary people to enter certain markets [27].

According to the company PwC, by 2025, the five largest sectors of sharing - car sharing, travel, crowdfunding, recruitment, and distribution of video and music - will bring up to $\$ 335$ billion. (from $\$ 15$ billion in 2015). The sharing concept also helps to reduce the negative environmental impact. A study by the World Economic Forum showed that in 2016, during the Rio de Janeiro Olympics, landlords registered on Airbnb (an online platform for accommodation, search, and short-term rentals of private housing) took the number of tourists equivalent of 257 hotels. Thanks to the sharing, the city avoided constructing new facilities, which means a lower use of natural resources and less greenhouse gas released into the atmosphere. According to Shareable.net (a non-profit 
organization analyzing sharing initiatives from around the world), there are urban sharing projects in almost every region of the world: from North America to Oceania [28].

Sharing economy platforms transform traditional production and consumption systems in cities around the world. Ways to benefit from the sharing economy's advantages, despite the significant number of Russian and foreign publications [29-36], are still poorly understood. Many of them aimed at developing this issue's theoretical aspects [37-41]. At the same time, it is now of utmost importance to study the roles, prospects, and effects of both resource owners, users (individuals and businesses), enterprises, and municipal authorities, taking into account the development of territories and the platforms of interaction, including Russian ones. Let us look at this sharing economy's development aspect on the example of the Moscow real estate market, taking into account the environmental impact of the large-scale housing renovation program.

\section{Materials and methods}

Systematization, structural, comparative analysis, a theoretical generalization of data obtained from a detailed analysis of literary and statistical sources were used.

\section{Results}

Housing's environmental situation consists of three components: the environmental situation, a house, the adjacent land plot, and an apartment. They are closely related to other factors that determine the housing cost. The ecological factor in housing cost depends, firstly, on each buyer's idea about what is a good and bad environment of the territory, and secondly, the established stereotypes and visual evaluation. In this article, we have identified several digital environmental IT-platforms, improving the efficiency of transfer and use of information resources (a basic sharing principle, to improve the efficiency of resources and information, in this case - on the environment) on the environmental situation in Moscow and the region to inform the public about the opportunities and the primary environmental risks when buying or building a house. Let us take a closer look at them.

\subsection{Interactive ecological map of the Moscow Region showing landfills and radiation hazard objects}

Since 2017, Moscow has been implementing a housing renovation program, a unique program of the Moscow Government, aimed at settling and demolition of dilapidated lowrise housing stock, built in 1957-1968, and new construction on the vacated territory. In 2019 , there were about 8 million tons of construction and demolition waste of IV-V classes of hazard in Moscow, comparable to the total amount of solid municipal waste ( 8.1 million tons per year). Considering the renovation program, the volume of construction waste in Moscow in 2020 will increase by 500 thousand tons per year - to 8.5 million tons. Now, the facility construction covered by the Moscow budget, and the renovation program generates $70 \%$ of the total amount of construction waste and commercial projects - the remaining $30 \%$ [42]. The appearance of this amount of additional waste and issues related to the reduction of greenery due to the construction of new residential complexes cannot but worry about the capital's residents. Fig. 2 presents an interactive environmental map of the Moscow Region, showing the landfill sites located close to Moscow (black and white mark) and radiation hazard objects (black and yellow mark). KvartiraZaMkad.ru portal developed 
this map based on open information sources such as Wikimapia and Wikipedia. This map can be useful when buying housing both in the secondary market and in a new building.

As it follows from Fig. 2, Moscow is surrounded by landfills, and the renovation program with planned demolition and construction waste rates will also adversely affect the current situation. It is noteworthy that in 2018 , there has been published the "Territorial scheme of waste management,"[43] which shows that in the Moscow Region (including Moscow), there are more than 3 thousand organizations producing construction, soil, and demolition waste (CSDW). More than $60 \%$ of CSDW is produced within $20-30 \mathrm{~km}$. from the Moscow Ring Road. At present, there is no control over transportation and the use of CSDW generated in Moscow. Once again, we emphasize it - there is no control. We want to highlight that construction and demolition wastes belong to IV-V hazard classes.
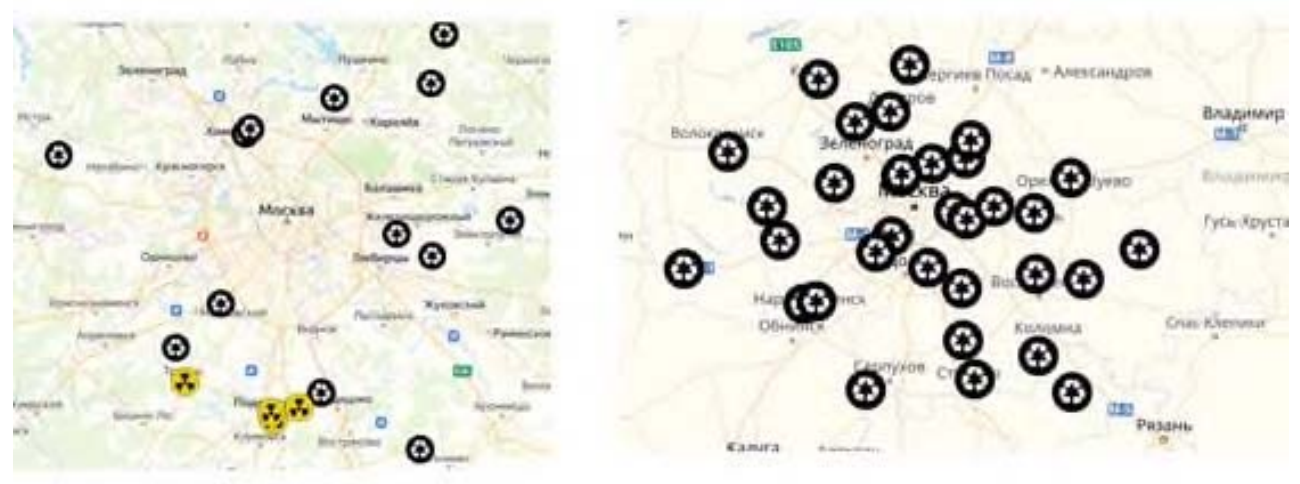

Fig. 2. Interactive ecological map of the Moscow Region showing landfills and radiation hazard objects [44].

According to the same document, a waste flow chart (Fig. 3) shows that the waste of IV-V hazard classes is placed either in landfills or in dumps, which may aggravate the problem of the Moscow Region's environmental safety. It is especially noteworthy that the "smart demolition" technology currently used in the renovation program requires a significant transformation to reduce the environmental risks and increase the economic efficiency of the construction material reuse. "Smart demolition" is based on the mechanized demolition method, which results in heterogeneous low-quality stone materials with no guaranteed solidity. Simultaneously, phased dismantling of buildings by modern technologies will allow reusing eventual construction structures and materials in the construction of low-rise buildings, thus reducing their market value by 2-3 times.

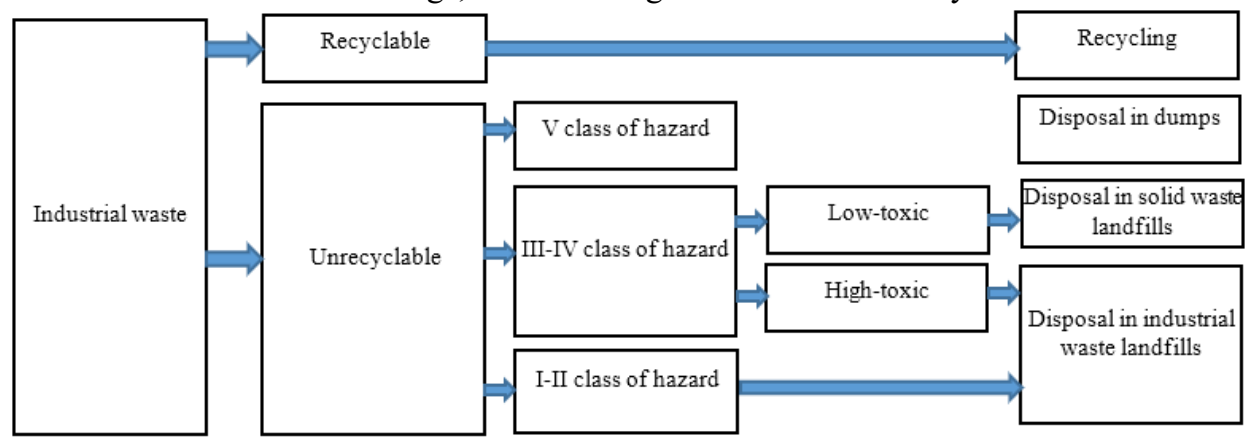

Fig. 3. Waste flow chart [45]. 


\subsection{Greenpeace's interactive map, "What Moscow breathes."}

Greenpeace's interactive map "What Moscow breathes" depicts information on the quality of the capital's air in real-time, indicating the content of harmful substances in the air (nitrogen dioxide, nitrogen monoxide, suspended particles 10 microns, suspended particles 2.5 microns, carbon monoxide, ozone, sulfur dioxide, hydrogen sulfide, ammonia, methane, toluene, benzene, styrene, formaldehyde, phenol) by Moscow districts. Fig. 4 presents information on nitrogen dioxide concentration in Moscow air for two different periods: the first chart - from 07.01.20 to 09.14.20; the second chart - from 08.13.2017 to 09.13.2017. It is seen that almost all Moscow administrative districts have environmental problems in 2020. In 2017, the North and North-East administrative districts started prevailing in terms of environmental problems.

It can be concluded that today neither the price per square meter of real estate, nor historical ideas about the environmental friendliness of the district, nor the presence of "green" zones do not guarantee the environmental cleanliness of Moscow districts and the real estate located in them. Before buying a real estate or a land plot, it is essential to order environmental expertise.

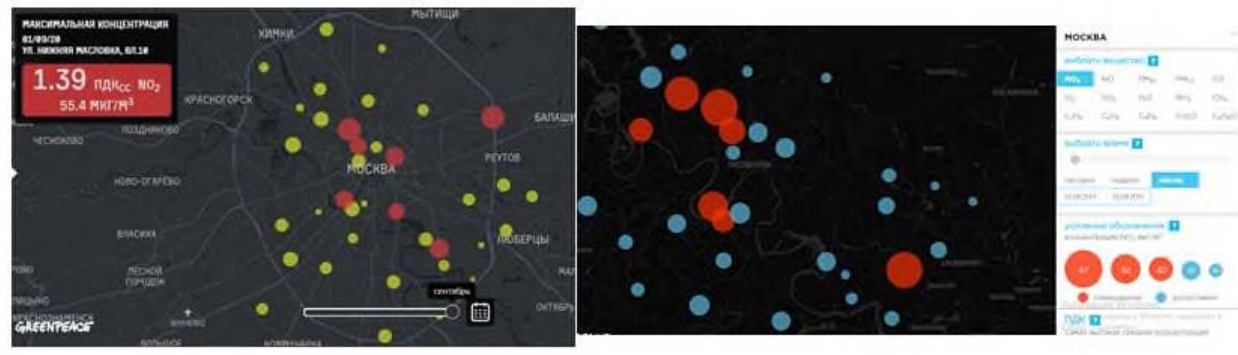

Fig. 4. Nitrogen dioxide concentration in Moscow air: (1) from 07.01.20 to 09.14.20; (2) for the period from 08.13.2017 to 09.13.2017 [44].

\subsection{Interactive map of the housing renovation program in Moscow}

This map shows houses demolished under the renovation program by the capital's administrative districts (Fig. 5). Distribution of demolished houses by Moscow Administrative Districts (AD) is as follows: the Central AD - 109 houses; the North-Eastern AD - 599; the Eastern AD - 1060; the Southeast AD - 818; the Southern AD - 378; the South-Western AD - 520; the Western AD - 558; the North-Western AD - 430; the Northern AD - 514; the Zelenograd AD - 34; the Troitsky and Novo-Moscow AD- 251. The apparent leaders in terms of the planned scale of demolition are the Eastern and SouthEastern Administrative Districts, which are also leaders in low air quality and ecologically unfavorable objects. Analysts of the Azbuka Zhilya company calculated by the example of the Moscow Eastern Administrative District (EAD) shows how the number of people in the district will change after the renovation program. According to the company's data, today, the EAD includes almost 75 thousand apartments in houses included in the preliminary list under demolition. On average, 2,5 people live in one apartment, so 190 thousand people live in the EAD. It is well-known that the number of people in new houses will be about 615 thousand, i.e., it will grow by 425 thousand people. Considering the population living in houses that are not subject to renovation, it can be estimated that renovation will increase the number of the EAD residents by $28 \%$ [33]. 


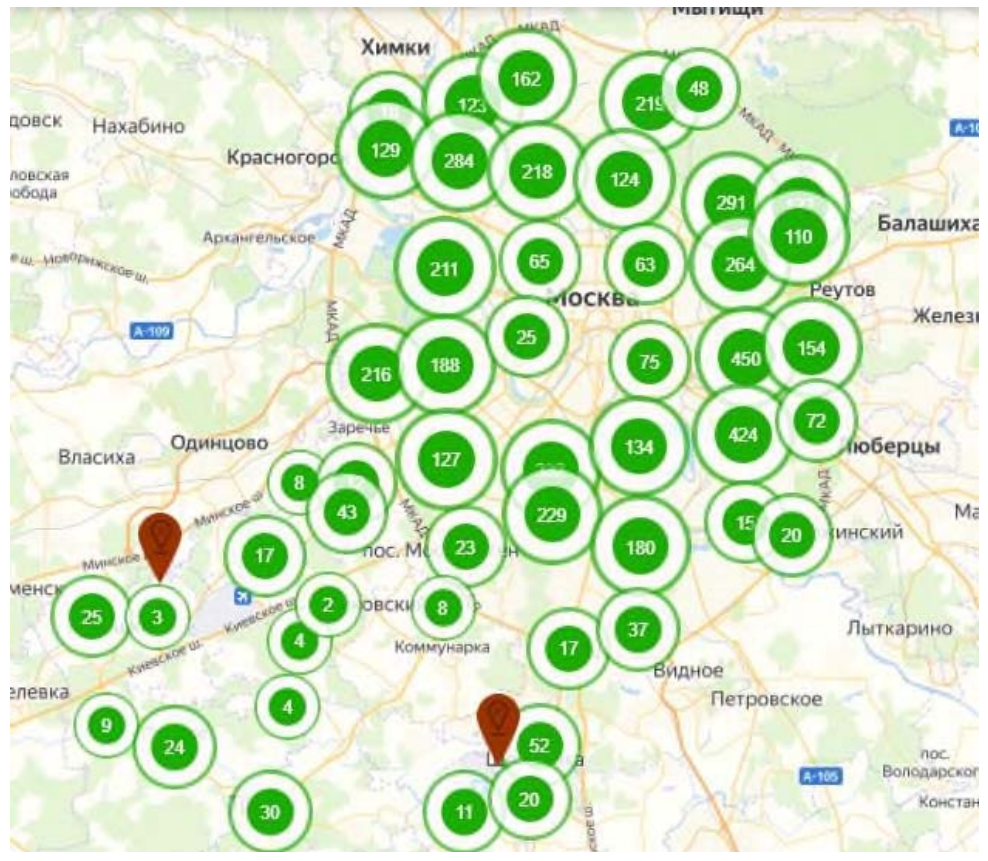

Fig. 5. Moscow renovation map [48].

At the same time, if we use the abovementioned interactive maps "What Moscow breathes" and ecological map of landfills, we can see that the EAD is currently one of the capital's most environmentally disadvantaged areas, which calls into question the feasibility of increasing this area development under the renovation program on a planned scale.

What can organizational and environmental measures be proposed in this situation?

\subsection{Use of the following indicators in the renovation program: environmental background of the development area and its environmental reserve}

In the conditions of increased environmental pollution of the air in Moscow and the housing renovation program, the following measures are of great importance [36-38]:

- To evaluate each administrative district of Moscow according to the following indicators: a degree of real estate concentration, level of sustainability coefficient, an environmental reserve of the territory, environmental safety threshold;

- To develop a list of measures to improve the quality of life and health of the population in each administrative district and improve environmental indicators based on the evaluation;

- To determine the volume of withdrawal to new territories of "superfluous" housing stock, industrial, commercial, and other enterprises.

The following indicators should be considered to determine the environmental safety for the assessed facility at the pre-project stage:

- Ecological background of the construction area determined by available sources, in our study - Greenpeace site "What Moscow breathes." Water and soil indicators are also subject to assessment and measurement. If the ecological background of the territory does not exceed the threshold limit values (TLV), it means that the territory has an environmental reserve. 
- The territory's environmental reserve (ER). The size of the territory's environmental reserve in a certain period is equal to the difference between TLV and ecological background, measured in TLV units.

For each time of day, weekday, and season, the environmental reserve has a size. If the ER value is equal to or less than 0 , the construction is not reasonable due to unfavorable environmental conditions. If the environmental reserve exists $(E R>0)$, construction is possible, but to more accurately determine the possibility of construction, it is necessary to assess the construction facility's humanmade load on the territory. The amount of environmental background and the facility's humanmade load should not exceed TLV at any time of day, week, year. Our study of Moscow air pollution dynamics, based on the "What Moscow breathes" website, revealed that the city has no environmental reserve of the territory in many administrative districts. Therefore, it seems necessary to develop and take measures to improve the quality of life and health of each administrative district's population, as well as Moscow's environmental indicators, and to review the renovation program's planned scope.

\subsection{Developing and taking measures to assess and improve the quality of life based on health saving indicators}

To date, there is a problem of transition from the goals to improve the Russian population's quality of life, specified in regulatory documents, to developing and taking measures to assess and improve the life quality in specific territories. These measures aimed at assessing and improving the life quality based on health saving indicators (HSI), an integral HSI indicator (IQ $\mathrm{HSI}_{\text {) }}$ and a management system for HSI are proposed [38]. The IQ HSI is considered as a weighted total of its system indicators (1):

$$
I Q_{\mathrm{HSI}}=\alpha_{1} K_{1}+\alpha_{2} K_{2}+\alpha_{3} K_{3}+\alpha_{4} K_{4}
$$

The following groups of indicators are used in the formula (1):

$K_{l}$ - the group "Indicators of health, injuries, and risk factors";

$K_{2}$ - the group "Environmental health indicators";

$K_{3}-$ the group "Health care quality indicators";

$K_{4}$ - the group "Lifestyle indicators."

These indicators were developed based on Russian scientists' research on life quality assessment; rating of Russian regions on the quality of life; foreign programs to assess the quality of life: "The European Core Health Indicators (ECHI) shortlist of 88 health indicators identified by policy area" [39]; "Health, United States, 2015: in Brief" [40]; "Measures of Australia's Progress" [41]; "Measuring national well-being in the UK in areas of life" [56]; "Annual report of Canada" [42]; "Annual statistical report of Japan" [43].

In this article, the group $K_{2}-$ "Environmental health indicators" is of most interest. It includes the following indicators: Air Quality Index; Water Quality [44]; Radiation Level; Degree of Soil Epidemic Hazard; Medical and demographic criteria applied in assessing the territory's environmental condition [45] (Complication of pregnancy and its outcome, total number of cases per 1000 pregnant women); Complication of childbirth, the total number of cases per 1000 pregnant women); Frequency of congenital malformations of newborns and spontaneous miscarriages; Unsatisfactory condition of premature newborns (assessment by Apgar scale, the number of cases per 1000 mature newborns). Frequency of newborns with bodyweight less than $2500 \mathrm{~g}$; Genetic disorders: increase in the frequency of genetic disorders in human cells (chromosome aberrations, DNA ruptures); Content in human bio-substrates (blood, urine, hair, teeth, saliva, placenta, female milk) of toxic chemicals, exceeding the permissible biological levels. 
It is proposed to apply quality management methods in the HSI management system (Fig. 6).

When developing the HSI management system, we consider its following definition: a systematic (strictly defined) set of means to collect information on the object and influence its behavior to achieve particular goals. The HSI management system's goal is to develop standards of citizens' health and safety in specific territories (taking into account the practice of development and application in St. Petersburg). These standards should be in the budgeting of regions, which will help assess the ability of regions to provide the citizens' necessary life quality. The development of citizens' living and health standards is vital according to the Presidential Decree of 05.07.2018 No. 204 "On the national goals and strategic objectives of the Russian Federation's development for the period up to 2024", which set such goals of the Russian Federation's development as ensuring sustainable natural growth of the Russian population; increasing life expectancy to 78 years (up to 80 years by 2030); the Presidential Decree of May 29, 2017. No. 240 "On Declaring the Childhood Decade in the Russian Federation" and others.

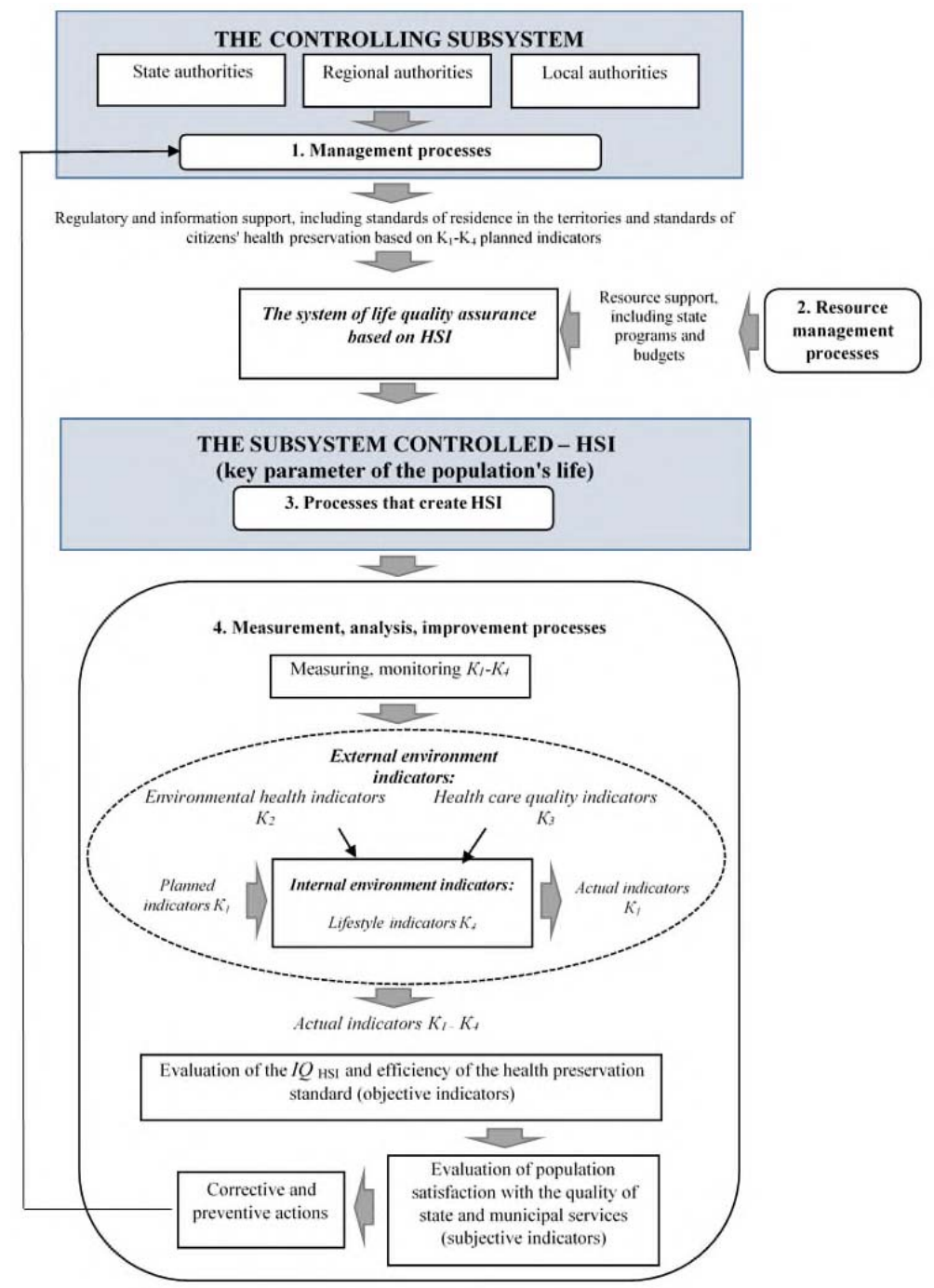

Fig. 6. HSI management system. 


\section{Discussion}

As we noted at the article's beginning, during the pandemic of Covid-19, it becomes essential to promote sustainable and promising forms of shared (distributed) use of resources. We looked at this sharing economy's development aspect on the example of the Moscow real estate market, taking into account the environmental impact of the large-scale housing renovation program. We have defined and described several digital environmental IT platforms aimed at improving the efficiency of transmission and use of information resources on the environmental situation in Moscow and the region in order to inform the public about the opportunities and the primary environmental risks when buying or building housing. These IT websites are free of charge for all users, and their information is updated either in real-time ("What Moscow breathes") or taking into account newly emerging information on the functioning of environmentally unfriendly objects in Moscow and the region (we mean, above all, landfills). The reliability of the information provided on the websites is a controversial issue, but it often allows a potential buyer to make a more detailed assessment of the area's environmental friendliness where he intends to buy housing. We have proposed organizational and environmental measures aimed at assessing and improving Moscow's population's life quality based on health indicators: use of the environmental background indicators of the development area, the area's environmental reserve, the integrated HSI indicator (IQ), and the HSI management system in the renovation program.

\section{Conclusion}

At present, the Russian Federation and Moscow have registered the growth dynamics of housing commissioning by the population. Moscow and the Moscow Region take far from leading positions in the country's dynamics. For example, the cost of land plots for individual construction is several times higher than in other regions. The possibility of saving on the construction materials' cost, which is the "outputs" of the phased analysis of houses in the renovation program, would be an effective way to motivate the individual construction of residential real estate in the Moscow Region and "New Moscow." Environmental IT platforms described in this article will help make an environmental assessment of the potential direction and district for construction or purchase of housing. It is unnecessary to be limited by them, but they can set the vector of the search for additional information.

Prepared as part of the state assignment of the Ministry of Science and Higher Education No. FSSW2020-0009 "Development of a methodology for managing the competitiveness of enterprises in the field of commodity circulation in the digital economy."

\section{References}

1. O. Ignatova Experts named the cities with the highest living standards in Russia

2. A.N. Schmeleva, Backgrounds and principles of drafting a standard of life quality in Moscow, QUALITY, 20(S2), 567-574 (2019)

3. A.N. Schmeleva, R.M. Nizhegorodtsev The program of housing renovation in Moscow and the environmental risks of the population, QUALITY, 20(S2), 574-579 (2019)

4. A.N. Schmeleva, R.M. Nizhegorodtsev Quality of life in Moscow: a monograph. Novocherkassk. M.I. Platov South-Russian State Polytechnic University, 163 (2019) 
5. A.A. Arnautova Digitalization of law-making activity, Century of quality, 2, 32-42 (2019)

6. T.A. Kuzovkova, T.Y. Salyutina, O.I. Sharavova Digital development's Influence on the organizational and methodological apparatus of communications' statistics and economy, Century of quality, 2, 106-119 (2019)

7. V.A. Rul'kova Application of modern digital technologies in industrial chain, Century of quality, 4, 42-53 (2018)

8. T.C. Tashibekov To a question on necessity of a modern information system of technical construction standards, Century of quality, 2, 84-99 (2017)

9. S.A. Filin "Smart Grid" - logical development of power supply systems, Century of quality, 2, 112-126 (2017)

10. V.S. Bychek, Yu.K. Kovaleva, A.I. Popov, V.V. Khrischev Digitalization of production: the essence of digitalization and its application at Samara's enterprises of heat networks, Molodezhniy Nauchny Vestnik,12 (37),207-211 (2018)

11. G.A. Gorbatov Digitalization in the state activity and its role in counteraction to corruption, Economy and society, 9(64), 85-90 (2018)

12. N.V. Gorodnova, V.V. Klevtsov, E.N. Ovchinnikov Prospects of telemedicine development in the conditions of Russian economy digitalization, Innovative economy questions, 9, 3, 1049-1066 (2019)

13. E.S. Levchenko New directions of education system digitalization, Intellectual resources - regional development, 5, 2, 73-75 (2019)

14. M. Dellenbaugh-Losse, Nils-E. Zimmermann, de Vries N. The Urban Commons Cookbook:Strategies and Insights for Creating and Maintaining Urban Commons

15. R. Botsman, R. Rogers, What's Mine Is Yours: The Rise of Collaborative Consumption, HarperBusiness (2010)

16. Räisänen Jaana, Ojala Arto, Tuovinen Tero. Building trust in the sharing economy: Current approaches and future considerations, Journal of Cleaner Production, 279, 10 (2021) 123724. https://doi.org/10.1016/j.jclepro.2020.123724.

17. Nakamura Hiroki, Abe Naoya, Mizunoya Takeshi. Factors inhibiting the use of sharing economy services in Japan, Journal of Cleaner Production, 278, (2021) 123981. https://doi.org/10.1016/j.jclepro.2020.123981.

18. Lim Weng Marc. The sharing economy: A marketing perspective, Australasian Marketing Journal (AMJ) (2020) https://doi.org/10.1016/j.ausmj.2020.06.007

19. Akande Adeoluw, Cabral Pedro, Casteleyn Sven. Understanding the sharing economy and its implication on sustainability in smart cities, Journal of Cleaner Production, 277, (2020) 124077. https://doi.org/10.1016/j.jclepro.2020.124077

20. Sands Sean, Ferraro Carla, Campbell Colin, Kietzmann Jan, Andonopoulos Vasiliki Vicki. Who shares? Profiling consumers in the sharing economy, Australasian Marketing Journal (AMJ). (2020) https://doi.org/10.1016/j.ausmj.2020.06.005.

21. A. Akhmedova, M. Mas-Machuca, F. Marimonb Value co-creation in the sharing economy: The role of quality of service provided by peer, Journal of Cleaner Production, 266, (2020) 121736. https://doi.org/10.1016/j.jclepro.2020.121736.

22. M. Laukkanen, N. Tura The potential of sharing economy business models for sustainable value creation, Journal of Cleaner Production, 253, (2020) 120004. https://doi.org/10.1016/j.jclepro.2020.120004. 
23. Curtis Steven Kane, Mont Oksana. Sharing economy business models for sustainability, Journal of Cleaner Production, 266, (2020) 121519 https://www.sciencedirect.com/science/article/pii/S0959652620315663.

24. N.I. Ivanova, V.I. Vlezkova, Yu.A. Logunova, Sharing economy in the world and Russia, Economics and management: scientific and practical journal,1, 19-22, (2020)

25. D.R. Igoshina Trends in development of joint consumption economy for 2020 , Innovative development of economy, 1 (55), 79-84 (2020)

26. Hossain Mokter. Sharing economy: A comprehensive literature review, International Journal of Hospitality Management, $\quad 87, \quad$ (2020) 102470. https://doi.org/10.1016/j.ijhm.2020.102470.

27. Nadeem Waqar, Al-Imamy Saifeddin. Do ethics drive value co-creation on digital sharing economy platforms, Journal of Retailing and Consumer Services, 55, (2020) 102095. https://doi.org/10.1016/j.jretconser.2020.102095

28. Gupta Parul, Chauhan Sumedha. Mapping Intellectual Structure and Sustainability Claims of Sharing Economy Research, A Literature Review. Sustainable Production and Consumption. (2020) https://doi.org/10.1016/j.spc.2020.09.006.

29. Nadeem Waqar, Juntunen Mari, Shirazi Farid, Hajli Nick. Consumers' value cocreation in sharing economy: The role of social support, consumers' ethical perceptions and relationship quality, Technological Forecasting and Social Change, 151, (2020) 119786. https://doi.org/10.1016/j.techfore.2019.119786.

30. J. Kauffman Robert, Naldi Maurizio. Research directions for sharing economy issues, Electronic Commerce Research and Applications, 43, (2020) 100973. https://doi.org/10.1016/j.elerap.2020.100973.

31. G. Northey Gavin, Brodie Rod. Leveraging the power of the sharing economy, Australasian Marketing Journal (AMJ).

(2020) https://doi.org/10.1016/j.ausmj.2020.06.015.

32. Pawlicz Adam. Pros and cons of sharing economy regulation. Implications for sustainable city logistics, Transportation Research Procedia, 39, 398-404 (2019) https://doi.org/10.1016/j.trpro.2019.06.042.

33. M. Ritter, H. Schanz The sharing economy: A comprehensive business model framework, Journal of Cleaner Production, 213, 320-331 (2019) https://doi.org/10.1016/j.jclepro.2018.12.154.

34. A.D. Adactylos, M.S. Chaus, A.A. Moldova Sharing economy, Economics,4 (36), Pages 95-100, (2019)

35. M.S. Ahmadieva Crowdfinance, state, and prospects of development at the modern stage, Symbol of science, 1, 4, 36-44 (2017)

36. V.V. Glukhov, Z.V. Glukhova Economy of joint consumption as a new form of economic relations, Waste and resources, 6, 4, 10 (2019)

37. E.D. Platonova Investigation of the genesis and evolution of the sharing economy concept in foreign publications (on the Scopus database's materials), Vestnik of Eurasian Science, 11, 1, 34 (2019)

38. A.G. Sadovskaya Main aspects of the sharing economy functioning, Vestnik of modern research, 9, 4 (24), 252-254 (2019)

39. S.A. Kolodyazhny, S.N. Zolotukhin, A.A. Abramenko, E.A. Artemova Demolition of the buildings and use of the materials formed at the urban areas renovation, Vestnik $M G C U, 15,2,271-293$ (2020)

40. The number of people in the WAD will increase by $28 \%$ after the renovation 
41. A.L. Bolsherotov Conceptual approaches to development of Moscow and its new territories, Housing construction, 5, 33-37 (2012)

42. A.L. Bolsherotov, L.V. Bolsherotova Structure of complex ecological safety of construction, Housing construction, 4, 52-57 (2012)

43. A.L. Bolsherotov, L.V. Bolsherotova Concentration of construction technogenic elements as a factor of negative emergent influence on environment and human health, Housing construction, 8, 28-30 (2012)

44. A.N. Shmeleva Improvement of quality of life in the system of coordinates: Institute of quality of management - health indicators, Drukerovsky Vestnik, 5(25), 16-33 (2018)

45. The European Core Health Indicators (ECHI) shortlist of 88 health indicators identified by policy area 